\title{
Comparison of policy preferences on conserving and sustainably utilizing the Can Gio mangrove forest by conjoint analysis method
}

\author{
- Võ Thị Minh Hoàng \\ University of Science, VNU-HCM \\ - Watanabe Mikihiko \\ Yamanashi University, Japan \\ (Manuscript received on March $20^{\text {th }} 2013$, accepted on January $18^{s t} 2014$ )
}

\begin{abstract}
The aim of this research is to evaluate partially economic values of Can Gio mangrove forests in Vietnam, using conjoint analysis, in respect to climate change adaptation, biodiversity conservation, and disaster protection. Vietnamese and Japanese people were selected as respondents to the questionnaire. Through analysis of collected data on two different mother populations, using linear regression model (or ordinary least squares model) in
\end{abstract}

econometrics, it was found that Vietnamese people were willing to pay highest value for tsunami protection, closely followed by climate change adaptation, and lowest value for biodiversity conservation while Japanese people in general gave their preferences to either adaptation measures or tsunami protection. As in conclusion, disaster protection functions should be the focus for future policies for all stakeholders and nonstakeholders.

Keywords: Economic evaluation, mangrove forest, conjoint analysis, willingness-to-pay, climate change adaptation, biodiversity conservation, disaster protection, tsunami, policy preferences.

\section{INTRODUCTION}

Firstly, Vietnam is very vulnerable to climate change. Officially endorsed reports suggest that Vietnam's average annual temperature has risen by $0.5-0.7^{\circ} \mathrm{C}$ in the last 50 years. A sea level rise of $20 \mathrm{~cm}$ in the corresponding period, combined with an annual increase in the frequency of tropical storms by 2.15 events and a significant decrease in mangrove forests, have magnified the impact of storm surges on coastal areas (Powell et al, 2009, pp. 2-3). Secondly, from the viewpoint of biodiversity, mangrove forests are

regarded to be one of the most important biodiversity-rich areas. Due to the statement "By $2020 \ldots 10$ per cent of coastal and marine areas, especially areas of particular importance for biodiversity and ecosystem services, are conserved through effectively and equitably managed... (Secretariat of the Convention on Biological Diversity, 2010)", it is clear that mangrove forests are to be researched from the viewpoint of biodiversity conservation. Thirdly, mangrove forests are studied to have functions 
that prevent disaster and mitigate, for instance, attacks of tsunami. They, at least, block rubbles in tsunami and decrease damages on sufferers. Especially, in this opportunity after devastating earthquake and tsunami happened on 3rd March 2011 in Japan, nothing can prevent from researching disaster prevention by mangrove forests. Fourthly and lastly, from the viewpoint of economic values of the environment that has been emerged in the last few decades, mangrove forests do not exist solely for biodiversity, they have multiple functions and economic values that contain values related with factors mentioned above. Through these backgrounds, it can be said this research is significant from the viewpoints of evaluating multiple benefits of the mangrove forests.

Various groups of respondents were delimitated in the hope of obtaining reliable questionnaire results. In detail, there were five types of respondents were chosen to be interviewed: Vietnamese students, Vietnamese tourists, Vietnamese who are both living and not living in Ho Chi Minh City, Japanese students and general Japanese people. Among them, Ho Chi Minh people and students who are living in Ho Chi Minh City are considered as biasedrespondents because they are living in or around the research site, while non- Ho Chi Minh people and tourist respondents are not. In a similar way, Vietnamese people were believed to have less objective perspective on the concerned matter than Japanese people. The mixture and comparison of biased and non-biased respondents is expected to present reliable estimation results.

Ultimately, the purpose of this paper is to estimate preferences of respondents, on the measures for tackling global environmental issues of climate change, biodiversity loss and natural disasters. Based on this estimation, some useful interpretations on how people behave to the future policies that can be formulated in the research site, and in which way the Can Gio mangrove forest can be best sustained and utilize in order to benefit stakeholders. Furthermore, through their willingness-to-pays on enhancing every combination of these mentioned above functions of Can Gio mangrove forest, the author eventually could come up with policy recommendations on planning or decisionmaking, concretely in the research site.

\section{PREVIOUS RESEARCH}

This research will be able to provide data using a new method, conjoint analysis, of which one of the advantages is that it allows the researchers to measure the relative values of attributes that have been considered jointly by respondents (Alriksson, S. and Öberg, T. 2008, pp. 244). This method also enables assessments on how the respondents state their preferences on certain products or certain functions of nature. Recently, several researches using conjoint analysis as a methodology have successfully been applied to solving practical environmental issues (Arifin, B. et al 2009, Hurlimann, A., McKay, J. 2006, Sayadi, S. et al 2005, Veisten, K. 2006).

In terms of the preceding research on economic evaluation of multiple functions of mangrove forest using conjoint analysis, there are very few ones that can be found in Vietnam. However, there have been some research conducted to evaluate the economic values of mangrove forest, two of them can be listed here as: Economic evaluation studies of mangrove conservation and rehabilitation in $\mathrm{Nam} \mathrm{Ha}$ Province, studied by N. H. Tri et al, using TEV approach and some mathematical models; Economic valuation of Can Gio Mangrove forest in Ho Chi Minh City, included in the project "Towards a Vietnam Wetlands Conservation and Management Program", (2000), namely "Valuation of the mangrove ecosystem in Can Gio Mangrove Biosphere Reserve, Vietnam" conducted by Environmental Department with

\section{Trang 86}


support of Holland Government. The latter report used an approach on economic valuation - Total Economic Value (TEV) as a method to estimate the direct use values and non-use values of the Can Gio Mangrove. Although this is a common method being used frequently in the economic field but still contained some limitations. In general, using TEV is easy to define and assess direct and indirect benefits of mangrove conservation, but the option and existence value of mangroves are difficult to determine within an economic analysis. One of the reasons of this limitation is the ambiguity of TEV's definition, so value cannot be estimated precisely.

\section{THE NEED OF ADAPTATION, CONSERVING BIODIVERSITY AND PROTECTING FROM DISASTERS IN CAN GIO}

The biodiversity in Can Gio Mangrove Forest is relatively rich. It was recognized as an international Biosphere Reserve by UNESCO in 2000. Nevertheless, actually the biodiversity in Can Gio Mangrove forest is suffering from the threats of human activities. Before 1987, there were a few Crocodylus porosus that lived in the wild environment in Can Gio Mangrove forest. However, due to the over-exploitation and poor conservation and management, they and two species of snakes have been discovered to be disappeared in the wild environment but some crocodiles currently being fed in cages in the forest for ecotourism purpose only. It is therefore imperative to conserve this endangered species.

In addition, it was recorded that the average global sea level has risen considerably for the past 100 years. Especially, Can Gio District in Ho Chi Minh City is coastal lowland that will be strongly affected by climate change and sea level rise. In fact, in many years, erosion has occurred along the coast and estuary and frequent flooding have been observed in many areas in this district. Particularly, among one town and six communes of Can Gio district, Tam Thon Hiep commune is regarded as the place facing the risk of inundation/flooding the most due to climate change and its geomorphologic characteristics (Channel of Information on Sustainable Development official website). Recently, Ho Chi Minh City's People Committee has directed Can Gio district's authorities as well as coordinated with other departments in implementing a subproject to relocate 84 households living along the Long Tau River out of An Loc village, Tam Thon Hiep commune which is facing a high risk of landslide. Ho Chi Minh City's authorities also propose some measures to deal with the consequences caused by climate change especially in the areas vulnerable to these issues. One of the measures of climate change adaptation in line with global trends and according to the UNFCCC is effectively planting diverse population of trees in mangrove forests. Based on the reasons mentioned above, thus, Tam Thon Hiep commune, Can Gio district is supposed to be a pilot area for mangrove plantation.

\section{CONJOINT ANALYSIS FOR POLICIES PREFERENCES IN CAN GIO MANGROVE FOREST}

This paper adopts conjoint analysis to verify how people in Vietnam evaluate importance of environmental protection policies that consist of climate change adaptation, biodiversity conservation and disaster protection. Theoretically, the conjoint analysis method is a standard statistical technique used in the field of marketing to know consumers' preferences on characteristics of products so that the new features of the new products could be determined and how they should be priced (Watanabe, 2012). Conjoint analysis regards characteristics of the commodities as attributes and levels. Therefore, in this study, the importance of each attribute will be determined considering the Can 
Gio mangrove forest conservation as a commodity. The data for analysis are collected by administering questionnaires. The answers to the questionnaires by respondents become the data for analysis. In addition, conjoint analysis is based on consumer theory, especially the levels of utility and compensated demand. Amongst three methods available by conjoint analysis such as choice experiment, ranking, and full profile rating, the full profile rating method is chosen in this paper. In the full profile rating method, ordinary least-square method is used for estimation.

\section{Questionnaire Design - Attributes and Levels}

Three attributes and levels have been chosen in order that three important elements of biodiversity in Can Gio can be focused. The attributes and levels are described in Table 4.1-1. The reason why Levels 1 of attribute of Tax are different amongst that for different types of respondent is that the budget constraints were expected to be different among them. Answers of questionnaire (i.e. estimation) cannot enjoy significant results unless respondents mind their budgets to pay tax.

Table 4.1-1 Attributes and Levels for Questionnaires

\begin{tabular}{|c|c|c|c|c|}
\hline Levels & $\begin{array}{c}\text { Climate } \\
\text { Change } \\
\text { Adaptation }\end{array}$ & $\begin{array}{c}\text { Biodiversity } \\
\text { Conservation }\end{array}$ & $\begin{array}{c}\text { Protecting } \\
\text { Local People } \\
\text { from Tsunami }\end{array}$ & $\begin{array}{c}\text { Tax } \\
\text { (dong/year) }\end{array}$ \\
\hline 1 & $\begin{array}{l}\text { Mangrove } \\
\text { Plantation in } \\
\text { Tam Thon } \\
\text { Hiep }\end{array}$ & $\begin{array}{l}\text { Subsidies for } \\
\text { captive breeding } \\
\text { crocodile }\end{array}$ & $\begin{array}{l}\text { Plant } \\
\text { Rhizophora } \\
\text { along the coast }\end{array}$ & $\begin{array}{l}\text { Vietnamese student: } 50000 \mathrm{VN} \text { dong } \\
\text { Vietnamese tourists and citizens: } 25 \\
000 \mathrm{VN} \text { dong } \\
\text { Japanese students and Japanese } \\
\text { citizens: } 5000 \text { yen }\end{array}$ \\
\hline 2 & No plantation & Doing nothing & $\begin{array}{l}\text { No action for } \\
\text { tsunami } \\
\text { prevention }\end{array}$ & $\begin{array}{l}\text { Vietnamese student: } 50000 \mathrm{VN} \text { dong } \\
\text { Vietnamese tourists and citizens: } 25 \\
000 \mathrm{VN} \text { dong } \\
\text { Japanese students and Japanese } \\
\text { citizens: } 2000 \text { yen }\end{array}$ \\
\hline 3 & --- & --- & --- & $\begin{array}{l}\text { Vietnamese student: } 5000 \mathrm{VN} \text { dong } \\
\text { Vietnamese tourists and citizens: } 5000 \\
\text { VN dong } \\
\text { Japanese students and Japanese } \\
\text { citizens: } 500 \text { yen }\end{array}$ \\
\hline
\end{tabular}

Source: Arranged by Author

\section{Data Collection}

There were a total of 170 questionnaires collected during the primary survey carried out in November 2011 in Vietnam using face-to-face approach. In the secondary survey that was conducted online in Japan from December 2011 to January 2012, there were 336 questionnaires collected via the Internet in total (after excluding those that had errors).

\section{Estimation models}

Importance evaluated by respondents can be estimated by the model below.

\section{Trang 88}


$\mathrm{Y}=\mathrm{a}+\beta 1 . \mathrm{CC} 01+\beta 2 . \mathrm{CC} 02+\beta 3 . \mathrm{BC} 01$ $+\beta 4 . \mathrm{BC} 02+\beta 5 . \mathrm{DP} 01+\beta 6 . \mathrm{DP} 02+\beta 7 . \mathrm{TAX}+$ $\mathrm{u}(1)$

Where: Y: utility (preference score) for a particular combination of activities, with a given level of each attribute $\beta 1-7$ : coefficient of each attribute, respectively

a: constant

u: disturbance

Variables included in the estimation model (1) above are defined as follows:

CC01: Climate change adaptation

CC02: Climate change adaptation (Doing nothing)

BC01: Biodiversity conservation

BC02: Biodiversity conservation (Doing nothing)

DP01: Disaster prevention

DP02: Disaster prevention (Doing nothing)

Donation: Donation (VN Dong/year)
All of the above variables are dummy variables except tax. Normally, this kind of equation (multiple dummy variables) can be considered as "dummy trap" that can easily lead to the multi-colinearity, although it is rarely happening in reality. However, in order to minimize or avoid it, the estimation of each coefficient was conducted by generating equation (1) into four particular equation models being shown as below:

Model $1: \mathrm{Y}=\mathrm{a}+\beta 1 . \mathrm{CC} 01+\beta 3 . \mathrm{BC} 01+$ $\beta 5 . \mathrm{DP} 01+\beta$ 7.TAX $+\mathrm{u}$

Model $2: \mathrm{Y}=\mathrm{a}+\beta 2 . \mathrm{CC0} 2+\beta 3 . \mathrm{BC} 01+$ $\beta 5 . \mathrm{DP} 01+\beta 7 . \mathrm{TAX}+\mathrm{u}$

Model $3: \mathrm{Y}=\mathrm{a}+\beta 1 . \mathrm{CC0} 1+\beta 4 . \mathrm{BC} 02+$ $\beta 5 . \mathrm{DP} 01+\beta 7 . \mathrm{TAX}+\mathrm{u}$

Model $4: \mathrm{Y}=\mathrm{a}+\beta 1 . \mathrm{CC} 01+\beta 3 . \mathrm{BC} 01+$ $\beta 6 . \mathrm{DP} 02+\beta 7 . \mathrm{TAX}+\mathrm{u}$

By these models, coefficients for the variables have been estimated and are shown Tables 4.3-1 and 4.3-2 below. Except BC02 of the tourists, all the variables are found to be significant.

\section{RESULTS}

Tables 4.3-1 Estimation (Respondents of the Vietnamese Students)

\begin{tabular}{|c|c|c|c|}
\hline Variables & $\begin{array}{l}\text { Unstanda } \\
\text { coefficien }\end{array}$ & & $\begin{array}{l}\text { Willingness- } \\
\text { to-pay (dong) }\end{array}$ \\
\hline $\mathrm{CCO} 1$ & 1.136 & $*$ & 69,978 \\
\hline $\mathrm{CCO} 2$ & -1.136 & * & -69.978 \\
\hline BCO1 & 0.595 & * & 36,643 \\
\hline $\mathrm{BCO} 2$ & -0.595 & $*$ & $-36,643$ \\
\hline DP01 & 1.269 & * & 78,121 \\
\hline DP02 & -1.268 & $*$ & $-78,121$ \\
\hline Donation & 0.000016 & $*$ & \\
\hline
\end{tabular}

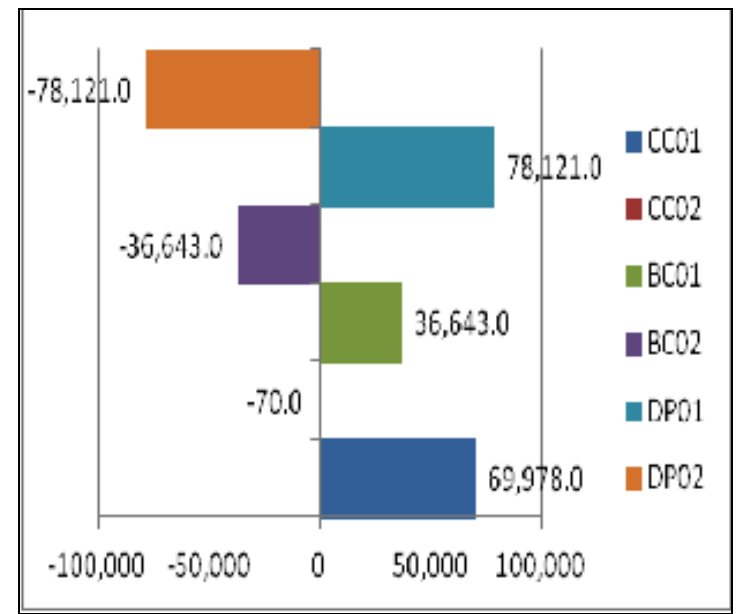


Vietnamese students identified their positive WTPs for enhancing the functions of Can Gio Mangrove forests, and absolutely negative for "Doing nothing" on any attribute. Specifically, the highest WTPs Vietnamese students ascertained towards Disaster Prevention with
78,121 VN Dong (3.91 US\$), almost the same value but little lower WTPs were placed on Climate Change Adaptation with 69,978 VN Dong (3.50 US\$). The lowest WTPs of Vietnamese students were shown towards Biodiversity Conservation.

Tables 4.3-2 Estimation (Respondents of the Vietnamese Tourists)

\begin{tabular}{|c|c|c|}
\hline Variables & $\begin{array}{l}\text { Unstandardized } \\
\text { coefficient }\end{array}$ & $\begin{array}{l}\text { Willingness- } \\
\text { to-pay (dong) }\end{array}$ \\
\hline $\mathrm{CCO1}$ & 0.949 & 306,513 \\
\hline $\mathrm{CCO} 2$ & -0.949 & $-306,513$ \\
\hline $\mathrm{BCO} 1$ & 0.469 & 151,608 \\
\hline $\mathrm{BCO2}$ & 0.027 & - \\
\hline DP01 & 0.980 & 316,400 \\
\hline DP02 & -0.980 & $-316,400$ \\
\hline Donation & $-0.00000310 *$ & \\
\hline \multicolumn{3}{|c|}{ *: Significant at $5 \%, \mathrm{R}^{2}=0.236$} \\
\hline
\end{tabular}

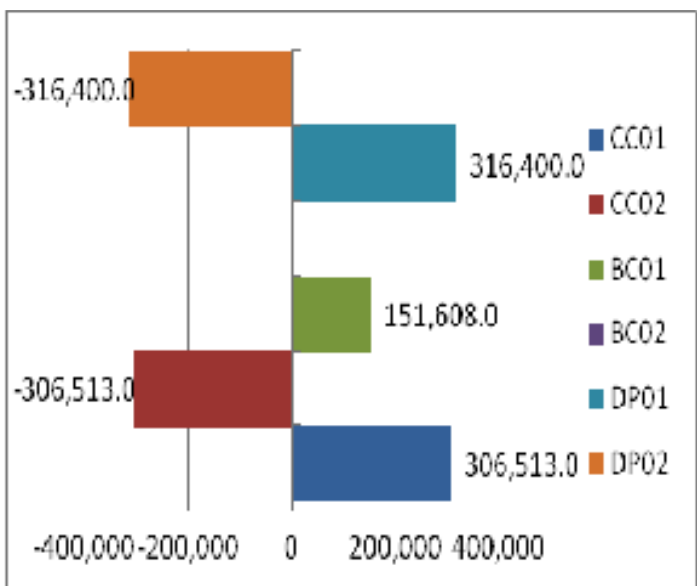

Similar to the results shown by Vietnamese students, Vietnamese Tourists showed their most positive attitude towards Disaster Prevention measures by the highest WTPs with $316,400 \mathrm{VN}$ Dong (15.82 US\$). The second priorities of this respondent type were focused on Climate Change

Adaptation with 306,513 VN dong (15.33 US\$), relatively high with regard to the GDP of Vietnam in 2010, that is 1,168 US\$ (Watanabe et al., 2012). Meanwhile the analysis of the results showed insignificances for Biodiversity Conservation attribute.

Tables 4.3-3 Estimation (Respondents of the Vietnamese citizens)

\begin{tabular}{|l|ll|l|}
\hline \multirow{2}{*}{ Variables } & \multicolumn{3}{|c|}{ Standardized coefficient } \\
\cline { 2 - 4 } & Ho Chi Minh people & \multicolumn{2}{l|}{ Non-Ho Chi Minh people } \\
\hline CC01 & 0.311 & $*$ & 0.243 \\
\hline CC02 & -0.311 & $*$ & -0.243 \\
\hline BC01 & 0.219 & $*$ & 0.038 \\
\hline BC02 & -0.086 & & 0.020 \\
\hline DP01 & 0.302 & $*$ & 0.102 \\
\hline DP02 & -0.302 & $*$ & -0.102 \\
\hline Donation & 0.048 & & -0.002 \\
\hline $\begin{array}{l}* \\
\text { at Significant }\end{array}$ & $R^{2}=0.238$ & \multicolumn{2}{|c|}{$\mathrm{R}^{2}=0.071$} \\
\hline
\end{tabular}

\section{Trang 90}


Regarding data collected from Ho Chi Minh City's inhabitants and Vietnamese citizens in other places of Vietnam, estimation results showed that the donation coefficients were not significant. However, by looking at the standardized coefficients from analysis, we can see that Ho Chi Minh City's inhabitants preferred Climate Change Adaptation the most

Tables 4.3-4 Estimation (Respondents of the Japanese Students)

\begin{tabular}{|l|lc|c|}
\hline Variables & $\begin{array}{l}\text { Unstandardized } \\
\text { coefficient }\end{array}$ & $\begin{array}{l}\text { Willingness- } \\
\text { to-pay (yen) }\end{array}$ \\
\hline $\mathrm{CCO} 1$ & $0.645 \quad *$ & $3,187.952$ \\
\hline $\mathrm{CCO2}$ & $-0.645 \quad *$ & $-3,187.952$ \\
\hline $\mathrm{BC0} 1$ & 0.105 & & -- \\
\hline $\mathrm{BC02}$ & -0.105 & & -- \\
\hline $\mathrm{DP01}$ & 0.717 & $*$ & $3,545.783$ \\
\hline $\mathrm{DP02}$ & -0.717 & $*$ & $-3,545.783$ \\
\hline Donation & -0.000202 & $*$ & \\
\hline *: Significant at $5 \%, \mathrm{R}^{2}=0.266$ \\
\hline
\end{tabular}

Crucial results were obtained by regression analysis of data collected from Japanese Students, these showed positive WTPs towards Disaster Prevention, with the highest WTPs by $3,187.952$ yen (40.631 US\$). (standardized coefficient is 0.311 ), followed by Disaster Prevention. While the same tendency in Vietnamese citizens who live outside of Ho Chi Minh City were also found (the highest standardized coefficient is for Climate Change Adaptation with 0.243 , followed by Disaster Prevention with 0.102).

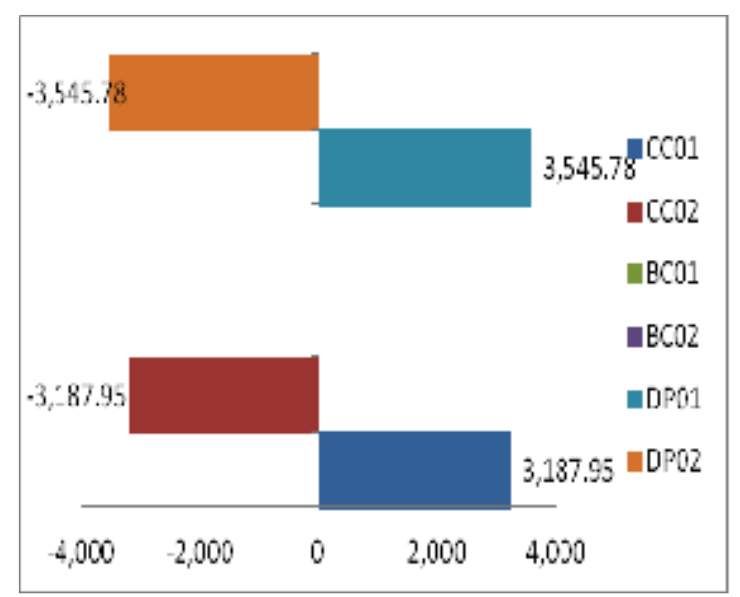

Tables 4.3-5 Estimation (Respondents of the Japanese Citizens)

\begin{tabular}{|l|lc|c|}
\hline Variables & $\begin{array}{l}\text { Unstandardized } \\
\text { coefficient }\end{array}$ & $\begin{array}{l}\text { Willingness- } \\
\text { to-pay (yen) }\end{array}$ \\
\hline $\mathrm{CCO} 1$ & 0.698 & $*$ & $3,534.700$ \\
\hline $\mathrm{CCO2}$ & -0.698 & $*$ & $-3,534.700$ \\
\hline $\mathrm{BC01}$ & 0.118 & & -- \\
\hline $\mathrm{BC02}$ & -0.118 & & -- \\
\hline $\mathrm{DP01}$ & 0.672 & $*$ & $3,406.940$ \\
\hline $\mathrm{DP02}$ & -0.672 & $*$ & $-3,406.940$ \\
\hline Donation & -0.000197 & $*$ & \\
\hline *: Significant at $5 \%, \mathrm{R}^{2}=0.300$ \\
\hline
\end{tabular}

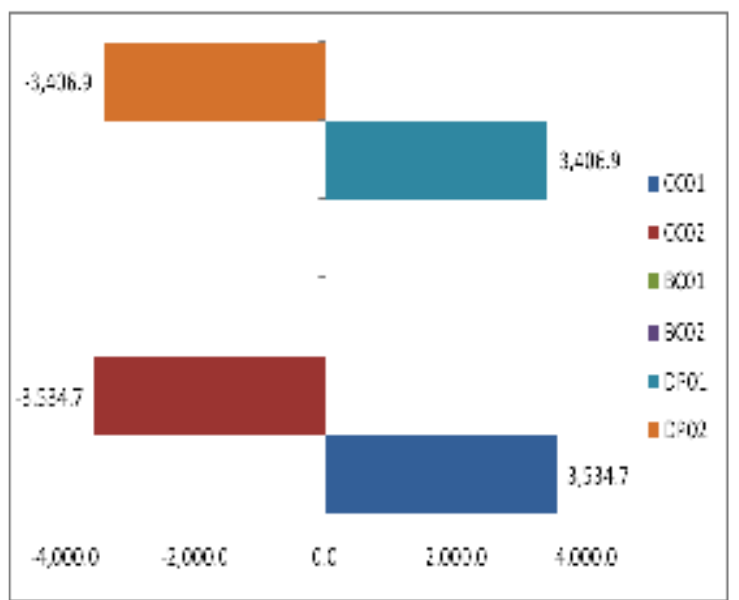

3,545.783 yen (45.191 US\$) and almost equally towards Climate Change Adaptation with

Trang 91 
Results of analyzing data collected from Japanese Citizens, exposed some interesting differences from estimation results obtained by Japanese Students, that the highest WTPs were placed towards Climate Change Adaptation with 3,534.700 yen (US\$). The second preference was put on Disaster Prevention with WTPs not much less than those on Disaster Prevention, 3,406.940 yen (43.422 US\$). The only similarity between results from Japanese Students and Japanese citizens is that the coefficients of Biodiversity Conservation attribute were found insignificant.

\section{CONCLUSION}

In brief, respondents' preferences were found on each attribute and shown in the table below. This table is used to offer a general image of above interpretations of estimation results and not in purpose of comparison between attributes, and/or between respondents.

Table 5.1. Policies preferences ascertained by respondents in brief

\begin{tabular}{|l|c|c|c|c|}
\hline \multicolumn{1}{|c|}{ Attributes Respondents } & $\begin{array}{c}\text { Climate } \\
\text { Change }\end{array}$ & $\begin{array}{c}\text { Biodiversity } \\
\text { Conservation }\end{array}$ & $\begin{array}{c}\text { Disaster } \\
\text { Prevention }\end{array}$ & Tax/donation \\
\hline Vietnamese students & 2 & 3 & 1 & Significant \\
\hline Vietnamese tourists & 2 & Insignificant & 1 & Significant \\
\hline HCMC's inhabitant & 1 & 3 & 2 & Insignificant \\
\hline Vietnamese in others places & 1 & 3 & 2 & Insignificant \\
\hline Japanese students & 2 & 3 & 1 & Significant \\
\hline Japanese citizens & 1 & 3 & 2 & Significant \\
\hline
\end{tabular}

Note: 1: most preferred, 2: second preferred, 3: least preferred

Firstly, it can be said that conserving Can Gio for tsunami prevention is the most important attribute for Vietnamese students and tourists (78,121 dong and 316,400 dong, respectively) even if they have not suffered from tsunami yet, they still are willing to pay very highly for tsunami prevention.

Secondly, climate change adaptation enjoyed very high appreciation by these two types of respondents (Vietnamese students and tourists) with almost the same WTPs values with disaster prevention attribute $(69,978$ dong and 306,513 dong, respectively). Basically, they are expected to understand the vulnerability of the areas that are suffering from sea level rise and facing high risk of unanticipated tsunami. In addition, the result can be interpreted that people have acknowledged the close relationship between negative effects of climate change and risks of tsunami.

Thirdly, deriving from the insignificances by Internet survey for Vietnamese people, amongst the estimation of all coefficients, tax/donation did not enjoy significance. This insignificance might be caused by questionnaire design, of which the donation amount chosen can be blamed as too low.

Fourthly, Japanese students have their highest WTPs on enhancing disaster prevention

\section{Trang 92}


functions of Can Gio Mangrove forest (3,545.783 yen vs. 3,187.952 yen, placed on disaster prevention vs. climate change adaptation, respectively) while Japanese citizens have the opposite tendency $(3,534.700$ yen vs. $3,406.940$ yen, placed on climate change adaptation vs. disaster prevention, respectively), even when they are suffering from serious tsunamis. Nonetheless, the gap between Japanese's willingness-to-pays on these two factors was not too large, it can be concluded that Japanese people appreciate either adaptation measures or tsunami protection in Can Gio mangrove forest.

\section{RECOMMENDATION ON ADAPTATION POLICIES IN CAN GIO}

Regarding the proposal of adaptation policy in Can Gio district, it should be mentioned first that there was not any specific policy being implemented in Can Gio district in terms of climate change adaptation. However, Ho Chi Minh City issued certain directives in terms of managing and conserving mangrove forest. These directives are revised, adjusted and edited annually. Currently, Can Gio district is implemented the directive no. 11/2011/CTUBND assigned by Ho Chi Minh City authority, indicated some policies on strengthening the conservation measures and sustainable development of the Biosphere Reserve Can Gio mangrove forest. The policy has an advantage of involving to community-based management, calling for responsibility and boosting participation of local community. However, the weakness of this policy is that there are no specific measures on preventing natural disasters or climate change adaptation or biodiversity conservation. Thus at the present time, there are no efficient ways to conserve Can Gio mangrove forest that directly benefit local people.

According to the analyzed results as above, three prominent functions of Can Gio mangrove forest that are regarded as benefits to stakeholders were not equally evaluated. Tsunami protection function has the highest value, closely followed by climate change adaptation function and biodiversity at last. In addition, although there are some differences between willingness-to-pays of each mother population, as unambiguously explained and discussed lately, a common tendency of policy preferences from all type of respondents as a whole was defined. Accordingly, disaster protection functions should be the focus for future policies for all respondents. Ultimately, the way of mangrove forest can be best sustained and utilized is for plantation of mangrove three (Rhizophora apiculata was shown as the best choice in this study) in Can Gio mangrove forest (Tam Thon Hiep commune was chosen as a pilot place - referring to section 4.2). This way can help in efficiently preventing tsunami and adapting to climate change. 


\section{So sánh các ưu tiên chính sách về bảo tồn và sử dụng bền vững rừng ngập mặn Cần Giờ - sử dụng phương pháp phân tích kết hợp}

- Võ Thị Minh Hoàng

Trường ĐH Khoa học tự nhiên, ĐHQG-HCM

- Watanabe Mikihiko

Trường ĐH Yamanashi, Nhật Bản

\section{TÓM TÁ́T}

Với mục tiêu nghiên cứu là định giá riêng phần giá trị kinh tế rừng ngập mặn Cần Giò̀ ở Việt Nam, úng dụng phương pháp phân tích kết hợp của nghiên cứu thị trường, bài báo này nhằm xác định giá trị kinh tế rừng ngập mặn theo 3 chức năng: thích ứng biến đổi khí hậu, bảo tồn đa dạng sinh học và chống thiên tai. Đối tượng được chọn cho việc thực hiện bảng câu hỏi là người Việt Nam và người Nhật. Trên cơ sở phân tích dũ liệu thu được sử dụng mô hình phân tích hồi quy tuyến tính trong kinh tế lượng, kết quả nghiên cứu cho thấy người Việt Nam ưu tiên

\section{REFERENCE}

[1]. B. Arifin, B.M. Swallow, S. Suyanto, R.D. Coe, A conjoint analysis of farmer preferences for community forestry contracts in the Sumber Jaya Watershed, Ecological Economics, 68, 7, 2040-2050 Indonesia (2009)

[2]. Asian Development Bank, Ho Chi Minh City Adaptation to Climate Change, Asian Development Bank (2010).

[3]. Can Gio Mangrove Forest Management Board, Introduction of Can Gio Mangrove Forest (2010). trước nhất là cho việc phòng chống thiên tai ở rừng ngập mặn, kế đến là thích ứng biến đổi khí hậu và giá trị thấp nhất của rừng ngập mặn là dành cho chức năng bảo tồn đa dạng sinh học. Trong khi đó, người Nhật ủng hộ một trong hai chức năng thích ứng biến đổi khí hậu hoặc chống thiên tai. Như vậy, kết luận chung của nghiên cứu sẽ là việc tập trung vào các hoạt động phát huy chức năng phòng chống thiên tai của rừng ngập mặn Cần Giờ, kết luận này căn cứ trên kết quả phân tích được của tất cả các đối tượng được hỏi, một cách tổng quát.

[4]. Channel of Information on Sustainable Development Official Website (in Vietnamese), Available at: http://www.vi.futureown.com/?p=1614

[5]. H.Q. Hai, Q.T.N. Tho, N.N. Tuyen, P.T.M. Tri, Preliminary Information on Coastal Erosion and Fallen Trees due to the Storms in Can Gio Area (in Vietnamese) (2010).

[6]. L.P. Hoang, Meiobenthos with special reference to free-living marine nematodes as bioindicators for different mangrove types in Can Gio Biosphere Reserve, Vietnam. Available online at: http://deposit.d-

Trang 94 
$\underline{\text { nb.de/cgi- }}$

bin/dokserv?idn=985684518\&dok_var=d1\& $\underline{\text { dok_ext }=\text { pdf } \& \text { filename }=985684518 . p d f}$ (2007).

[7]. A. Hurlimann, J. McKay, Urban Australians using recycled water for domestic nonpotable use - An evaluation of the attributes price, saltiness, colour and odour using conjoint analysis, Australia, Journal of Environmental Management, 83, 1, 93-104 (2006)

[8]. IMABE Project Official Website. Available online

at:

http://www.donimabe.org.vn/index.php?mod $=$ content\&id $=77$.

[9]. K. Kathiresan, N. Rajendran, Coastal Mangrove forest mitigated tsunami, Coastal and Shelf Science, 65, 601 - 606 (2005).

[10].E. McLeod, R.V. Sal, Managing Mangroves for Resilience to Climate Change, IUCN Resilience Science Group Working Paper Series - No 2, Available online at: http://data.iucn.org/dbtw-wpd/edocs/2006041.p (2006).

[11].D. Pearce, G. Atkinson, S. Mourato, CostBenefit Analysis and the Environment Recent Develpments, OECD (2006).

[12].E. Pelinck, Mangrove for production and protection - A Changing Resource System: Case Study in Can Gio District, Southern Vietnam, the FAO Regional Wood Energy Development Programme in Asia, Bangkok, Thailand (1993).

[13].N. Powell, M. Osbeck, S.B. Tan, V.C. Toan, World Resources Report Case Study:
Mangrove Restoration and Rehabilitation for Climate Change Adaptation in Vietnam (2009).

[14].S. Sayadi, M.C. González-Roa, J. CalatravaRequena, Public preferences for landscape features: The case of agricultural landscape in mountainous Mediterranean areas, Land Use Policy, Spain, 26, 2, 334-344 (2009).

[15].S. Sayadi, M.C.G. Roa, J.C. Requena, Ranking versus scale rating in conjoint analysis: Evaluating landsapes in mountainous regions in southeastern Spain, Ecological Economics, Spain, 55, 4, 539-550 (2005).

[16].(The) Secretariat of the Convention on Biological Diversity Aichi Biodiversity Targets, Available at: http://www.cbd.int/sp/targets/ (2010).

[17].Vietnamese News on Daily Events (in Vietnamse), Available at: http://www.baomoi.com/Di-doi-84-ho-danven-song-Long-Tau-CanGio/144/6681901.epi .

[18].United Nations Climate Change Factsheet The Effects of Climate Change in Viet Nam and the UN's Responses, Available at: http://www.un.org.vn/en/publications/publica tions-by-agency/doc details/111-climatechange-fact-sheet-updated-april-2011.html (2011).

[19].K. Veisten, Willingness to pay for ecolabelled wood furniture: Choice-based conjoint analysis versus open-ended contingent valuation, Journal of Forest Economics, Norway, 13, 1, 29-48 (2007). 